\title{
A 52-year-old man with cognitive decline, seizure and stroke
}

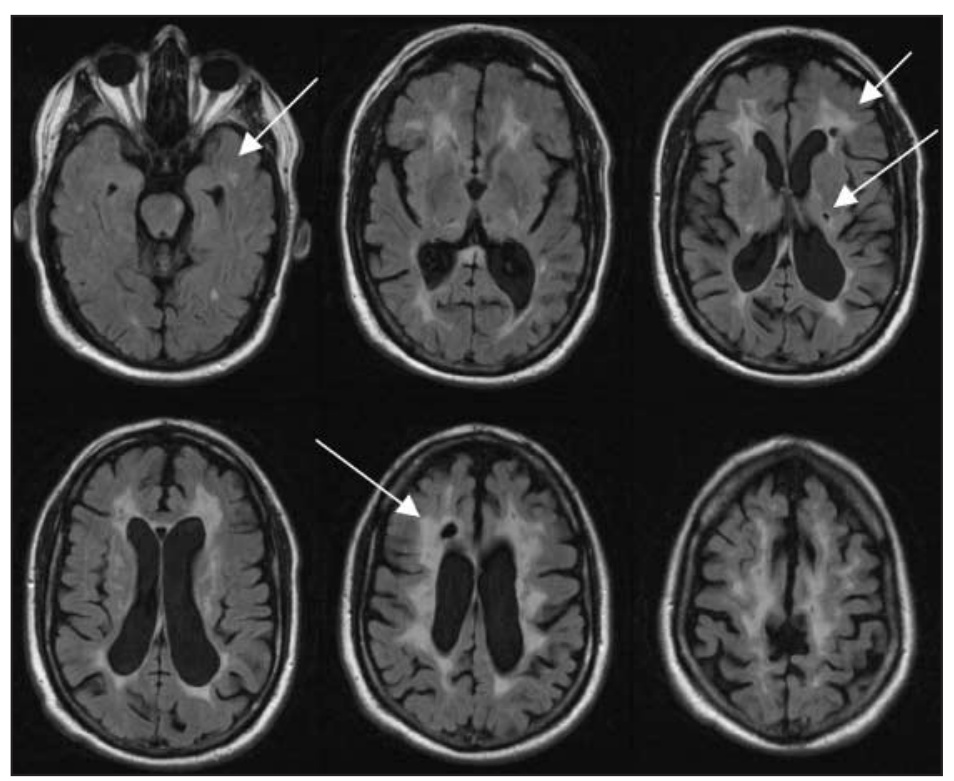

A 52-year-old right-handed Aman was referred to a neurologist for assessment of isolated progressive cognitive decline, which was significant enough for him to take early retirement. He had a remote history of headaches but no mood disorder and no family history of stroke, dementia or migraine. Assessment revealed a subcortical dementia with deficits in executive function, organization, sequencing and language. The usual causes of reversible cognitive dysfunction (depression, nutrient deficiencies, hypothyroidism and space-occupying lesions) were ruled out. Two years later he was admitted to hospital following a single, witnessed, generalized seizure. Fluid attenuated inversion recovery (FLAIR) axial MRI (Fig. 1) showed hyperintensity consistent with diffuse multifocal white matter disease with a left anterior temporal lobe lesion, $\hat{\kappa}$ and old bilateral cystic infarctions. Results of investigations for cerebral vasculitis, stroke, multiple sclerosis and metabolic causes of leukoencephalopathy were unremarkable. Mitochondrial encephalomyopathy was ruled out through muscle biopsy. However, electron microscopy of the muscle biopsy specimen showed electrondense, extracellular, osmophilic deposits in the endothelial basal lamina (Fig. 2, arrows), which suggested cerebral autosomaldominant arteriopathy with subacute infarcts and leukoencephalopathy (CADASIL). Three years later the man had a left internal capsule stroke resulting in paralysis of the right side of his body. Genetic studies performed on a sample of the man's blood confirmed an $\mathrm{R} 182 \mathrm{C}$ mutation in exon 4 of the Notch3 gene.

CADASIL is an autosomaldominant genetic stroke syndrome characterized by the triad of stroke or stroke-like episodes, migraine headaches and dementia. Strokes and transient ischemic attacks are the most common features. Psychiatric symptoms may occur and predominantly involve mood disorders. Seizures, although not considered part of the classic triad, may be more common than previously thought. Although patients often present at a young age, symptoms may not manifest until the eighth decade. Typically, MRI shows progressive, multifocal T2 hyperintense lesions, often involving the anterior temporal lobe, that may mimic multiple sclerosis. Although there may be few white matter abnormalities in children or young adults, they become confluent with age. Worldwide, about 200 families with CADASIL have been identified. The syndrome has been reported across many ethnic populations and, as a newly recognized condition, is probably underdiagnosed. Penetrance and prognosis are both highly variable.

CADASIL may be diagnosed by means of electron microscopy of skin or muscle tissue. New immunohistochemical techniques that target the Notch3 protein may eliminate the need for electron microscopy. ${ }^{1}$ The Notch 3 protein is conserved across species and was first identified in the fruit fly, Drosophila melanogaster, where it produces a notched wing phenotype. It is located on chromosome 19 in humans, but its exact role is still unclear. Specific mutations of the Notch3 gene, most commonly in exons 3 or 4 , produce a loss or gain of a cysteine amino acid in the resulting Notch3 protein that may alter its struc-

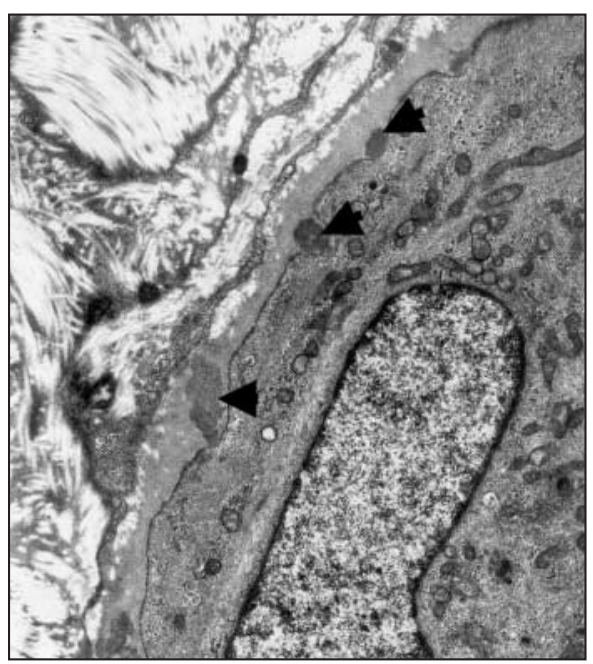


ture and lead to its abnormal catabolism. ${ }^{2}$ Patients with CADASIL are heterozygous for the mutation, and homozygosity may be incompatible with life. De novo mutations have been reported $^{3}$ and may have occurred in our patient, as neither of his parents had symptoms of the condition. Screening for the Notch3 mutation in young patients presenting with lacunar stroke is likely to have a poor yield in the absence of a family history or other clinical features of the disease. ${ }^{4}$ Diagnosis of CADASIL is important for prognosis of symptomatic patients as well as for counselling of asymptomatic family members who may be at risk. Our patient's children have not been tested to date. No specific treatment is currently available, but the current approach includes aggressive management of the major cerebrovascular risk factors of hypertension, smoking, diabetes and hyperlipidemia.

\section{Jessica E. Simon}

Calgary Stroke Program

University of Calgary

Jillian Parboosingh

Department of Medical Genetics

University of Calgary

Arthur Clark

\section{David George}

Division of Neuropathology

University of Calgary

Calgary, Alta.

Anne-Louise Lafontaine

Division of Neurology

McGill University

Montréal, Que.
Michael D. Hill

Calgary Stroke Program

University of Calgary

Calgary, Alta.

\section{References}

1. Joutel A, Favrole P, Labauge P, Chabriat H, Lescoat C, Andreux F, et al. Skin biopsy immunostaining with a Notch 3 monoclonal antibody for CADASIL diagnosis. Lancet 2001; 358:2049-51

2. Joutel A, Andreux F, Gaulis S, Domenga $\mathrm{V}$, Cecillon $\mathrm{M}$, Battail N, et al. The ectodomain of the Notch 3 receptor accumulates within the cerebrovasculature of CADASIL patients. 7 Clin Invest 2000;105:597-605.

3. Joutel A, Dodick DD, Parisi JE, Cecillon $\mathrm{M}$, Tournier-Lasserve $\mathrm{E}$, Bousser MG. De novo mutation in the Notch3 gene causing CADASIL. Ann Neurol 2000;47:388-91.

4. Dong Y, Hassan A, Zhang Z, Huber D, Dalageorgou C, Markus HS. Yield of screening for CADASIL mutations in lacunar stroke and leukoaraiosis. Stroke 2003;34(1):203-5.

\section{BOOKS ReCEIVED}

Atkinson K, Champlin R, Ritz J, Fibbe $W$, Ljungman $\mathrm{P}$, Brenner MK. Clinical bone marrow and blood stem cell transplantation. 3rd ed. Cambridge (UK): Cambridge University Press; 2004. 1968 pp. £215 ISBN 0-521-82912-7

Dubé L, Ferland G, Moskowitz DS. Emotional and interpersonal dimensions of health services: enriching the art of care with the science of care. Montréal and Kingston: McGillQueen's University Press; 2003. 200 pp. \$27.95 (paper) ISBN 17735-2562-9; \$70 (cloth) ISBN $0-7735-2561-0$

Grimes DA. Parkinson's: stepping forward. Toronto: Key Porter; 2004. 206 pp. \$19.95 ISBN 1-55263-266-0

Halmosi R, Sümegi B, Hideg K, Tóth K, Mózsik G. Prevention of oxidative cell injury with antioxiodants and poly (ADPRibose) polymerase inhibitors. Portland(OR): International Specialized Book Services; 2003. 82 pp. US\$19 ISBN 963-057951-0
Jessup M, McCauley K, editors. Heart failure: providing optimal care. Malden (MA): Blackwell; 2003. 264 pp. US\$69.95 ISBN 1-4051-0375-2

Keating P, Cambrosio A. Biomedical platforms: realigning the normal and the pathological in late-twentieth-century medicine. Cambridge (MA): MIT Press; 2003. 544 pp. US\$55 ISBN 0-262-11276-0

Kepron W. Cystic fibrosis. Toronto: Key Porter; 2004. 190 pp. \$19.95 ISBN 1-55263-481-7

Myers R. Heart disease. Toronto: Key Porter; 2004. 184 pp. \$19.95 ISBN 1-55263-268-7

Nelson JL, editor. Rationing sanity: ethical issues in managed mental health care. Washington: Georgetown University Press; 2003. $182 \mathrm{pp}$. US\$44.95 ISBN 0-87840-145-8

Nicholl DJ, Williams A. The clinical atlas of Parkinson's disease [CD-ROM]. Malden
(MA): Blackwell; 2003. US\$150 ISBN 1-4051-0778-2

Nihill MR. An angiographic atlas of congenital cariovascular anomalies [CD-ROM]. Malden (MA): Blackwell; 2003. U\$149.50 ISBN 1-4051-0377-9

Saibil F. Crohn's disease and ulcerative colitis. Toronto : Key Porter; 2003. 224 pp. \$19.95 ISBN 1-55263-543-0

Sourkes T. The life and work of J.L.W. Thudichum. Montréal: Osler Library McGill University; 2003. 95 pp. \$25.00 ISBN 0-77170-612-X

St. John-Sutton MG, Maniet AR. Atlas of multiplane transesophageal echocardiography. Vol. 1. London: Martin Dunitz; 2003. 481 pp. US\$430 ISBN 185317-217-0

St. John-Sutton MG, Maniet AR. Atlas of multiplane transesophageal echocardiography. Vol. 2. London: Martin Dunitz; 2003. 449 pp. US\$430 ISBN 185317-217-0 